\title{
An Experiential Introduction to Aerospace Engineering
}

\author{
P. D. Washabaugh ${ }^{*}$, L. A. Olsen ${ }^{\dagger}$, and J. M. Kadish* \\ University of Michigan, Ann Arbor, Michigan, 48109-2140
}

\begin{abstract}
An intensive course that introduces first-year students to an entire flight system is described. The course consists of four parallel and synergistically interwoven activities. These include (1) a sequence of team design-build-test projects, supported by (2) lectures and activities on scientific principles and engineering practice, (3) lectures and activities on technical communications and teamwork, and (4) individual labs on instrumentation and fabrication techniques. The final project involves the fabrication, testing and a competition of a lighter-than-air remote controlled vehicle that is designed for Martian operation but scaled to function in a terrestrial environment, accompanied by oral presentations and written reports on the blimp design, construction, and performance. The course is scheduled to have 6 contact hours per week over a 14-week term. Given its rigor and extensive time commitment, the course is unusually popular and has led to some desirable behavior in subsequent independent student projects.
\end{abstract}

\section{Introduction}

One means to help students select a field of study is to offer a variety of early courses that have different and distinct technical themes. The course described here, Engineering 100-700, is tailored towards first year students that have a passion for flight vehicles. The intent of this course is to introduce the system aspects of Aerospace Engineering in a broad manner to help students select a program of study and to meet first-year program requirements for any Bachelor of Science degree in the College of Engineering at the University of Michigan.

The primary motivation for this effort stems from our experience with student managed design-build-test projects, such as the Student Space Systems Fabrication Laboratory ${ }^{1}$ and the SOLUS Unmanned Air Vehicle project $^{2}$, two notable examples of student projects. Results from these projects appear in Figure 1. Both of these activities resulted in flight hardware and involved a hierarchy of students ranging from first-year undergraduates to experienced graduate students. The students were assisted by faculty, staff engineers, and technicians, who participated by being the Principal Investigator of external grants, by being advisors, and in some cases by overseeing directed studies and assisting with training in fabrication techniques. Alumni were also involved in terms of arranging donated equipment and time in the form of engineering reviews and technical advice.

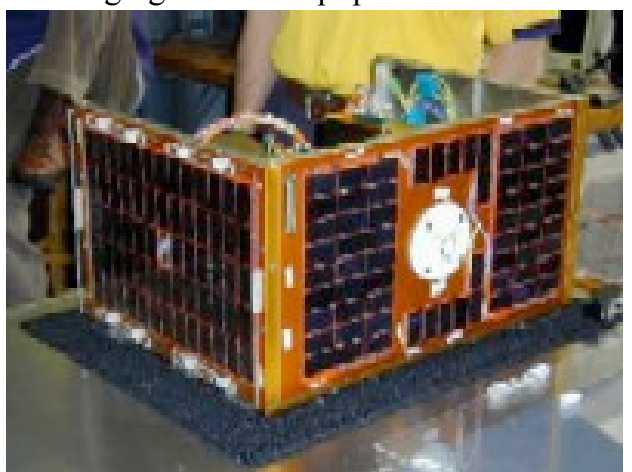

(a)

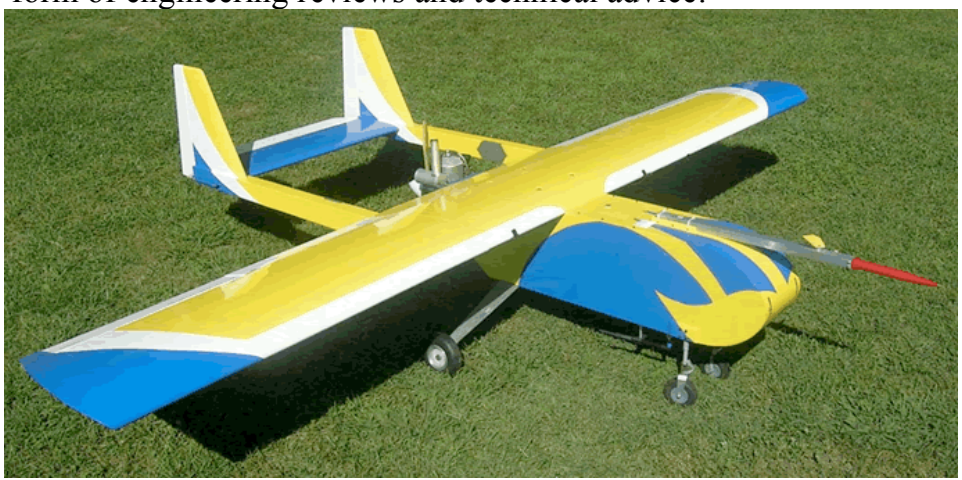

(b)

Figure 1. Flight hardware results of student managed design-build-test activities

(a) Partially assembled Icarus Student Satellite from the Student Space Systems Fabrication Laboratory: A $0.25^{\prime \prime} \times 13.65^{\prime \prime} \times 18.75^{\prime \prime}$ structure. ${ }^{3}$ (b) SOLUS Unmanned Air Vehicle with 11 foot wingspan and dual-computers ${ }^{4}$.

\footnotetext{
* Associate Professor, Aerospace Engineering, 1320 Beal Ave, Ann Arbor MI 48109-2140, AIAA Member.

† Professor, Technical Communications, 305 Engineering Programs Building, Ann Arbor, Michigan 48109-2101.

$\$$ Graduate Student, Mechanical Engineering
} 
The Icarus spacecraft had a mass of $21.3 \mathrm{~kg}$, was battery and solar-cell powered with an average power requirement of $12.5 \mathrm{~W}$. It was equipped with a magnetometer and GPS receiver to measure the dynamics of the spacecraft system. The SOLUS UAV was design and built by a student group with the assistance of a senior research engineer. The purpose of this craft is to act as a test-bed to ascertain intelligent flight control and trajectory planning strategies in the presence of faults. It not only involved the airframe and flight control development but the design of a dual-computer integrated flight control system.

Arguably one of the most spectacular features of both of these projects was the feed-back loop that developed between upper-level students mentoring and training their younger colleagues. In effect upper-level students were training underclassmen in a variety of technical and fabrication techniques, thereby creating an organically grown curriculum that was parallel with formal classes. These training and mentoring activities were essential components of these projects and were needed to make even first year students useful.

The result of this process was that students who spent a good fraction (e.g., 3 years or more out of a typical 4year program) participating in these design-build-test projects graduated with a wisdom far beyond their years. They not only had knowledge, but they knew how to apply it appropriately. Our very best students have participated in these activities and then graduated as colleagues with B.S. degrees.

The goal of the course described here is to benignly capture some of the educational content of these types of projects and to institutionalize this content as part of the formal curriculum. In effect, we take the laboratory training, the small preliminary projects, the technical (e.g. scientific principles, communications) and non-technical (e.g. teaming) instruction, and insert them into the curriculum so anyone with an interest can be involved. The hope is to expand these types of activities so that all our students graduate as wise colleagues.

\section{Course Approach}

Most first-year students have a tremendous enthusiasm and eagerness to immediately be engineers. Consequently, the primary focus of the first-year course described here (Engineering 100-700) is an engineering project that has a large number of technical issues, yet has feasible solutions that are not difficult to obtain: to design, construct, test, and compete with lighter-than-air vehicles, first a balloon and then a blimp. Lighter-than-air vehicles (e.g. balloons and blimps) are good candidates for these projects ${ }^{5}$. They can straight-forwardly be made to fly by making the gas envelope large enough, but to make them fly well entails more careful consideration. They have the attributes that their motion is slow and therefore easily observable. Their design for vertical motion and translation can mostly be decoupled; lift and weight considerations are not driven by thrust and drag. Here, to increase the wealth of technical issues, in our course the vehicles were specified to perform a mission on Mars, but the students were required to build an Earth-based model. This Martian-Earth dichotomy introduced a variety of engineering problems associated with aeronautics and astronautics and the scaling between the disparate environments.

The approach taken here is to assume that the students are to some degree already engineers and to introduce them to the final project on the first day of class. Even though there is an expectation by the instructors that the students will behave as engineers, it is understood that they are inexperienced, lack certain technical knowledge, and are unsure of their roles. Indeed the whole approach of the course is to work backward from the final project and to build-up the student's experience and technical expertise so that each individual is capable of performing the entire design, fabrication, and testing; of participating well on a team, and of producing competent technical reports and oral presentations.

\section{Course Format}

The Engineering 100-700 course inserted the students into a simulated engineering environment. The model used here for engineering is displayed in Figure 2. The practice of engineering generally lies somewhere between generators of societal needs, discoverers of new phenomena and those that build things. This arrangement does

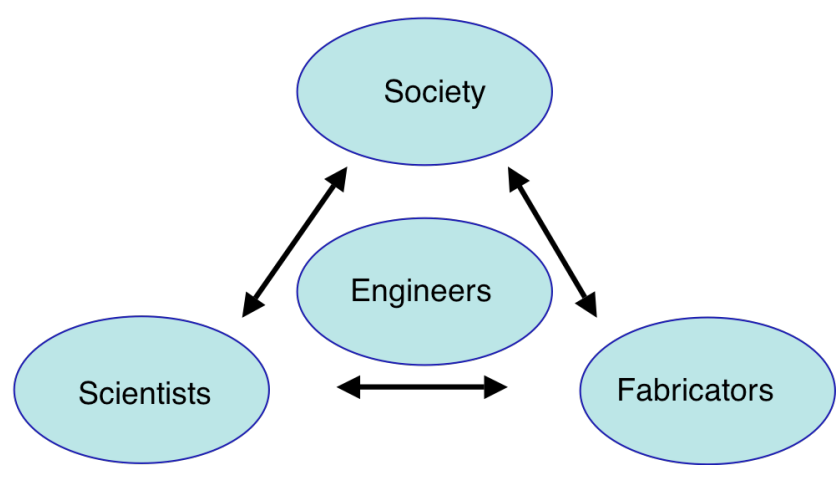

Figure 2. Engineering as an Interstitial Discipline The approximate interstitial placement of engineering with respect to social needs, scientific disciplines and fabricators. 
not preclude engineers themselves from social, scientific, or fabrication functions. It is intended to illustrate that engineering is mostly interstitial to other specialties. Engineers are, of course, members of society, but societal needs are generally defined by others. Similarly, engineers are knowledgeable about scientific principles and their application, but it is not typically their primary task to discover new phenomena. Likewise, engineers need to know how to fabricate their designs. Frequently what can be fabricated in a cost-effective manner drives a decision, but usually specialists such as machinists are tasked with the actual construction and manufacturing. The goal of this course was to introduce and exercise the specific linkages between the specifications of societal needs, physical principles, manufacturing, and their system-wide integration in a product. The course was organized around this model in that team projects were intended to encompass engineering, while there were supporting lectures and labs that dealt with the interfaces between society, science, and fabrication and between the team members themselves.

\section{A. Team Projects}

Our course contained four team activities. These were sequenced to provide common teaming experiences, each introduced by a discussion of teaming principles and followed by a debriefing/assessment of the teaming and technical aspects of the project. The team activities were also sequenced to provide introductory system-level technical exercises that culminated in a competition to fly reconnaissance blimps. An example of one of the blimps is shown in Figure 3.

Since the projects here are very involved and time-consuming, it is essential to engage carefully selected student teams and to insure that there are at least rudimentary skills at conflict resolution. All of the teams were nominally comprised of five students. This size was selected to allow challenging projects and the existence of teaming problems, but was sufficiently small to be manageable by the students and the instructors. The first two

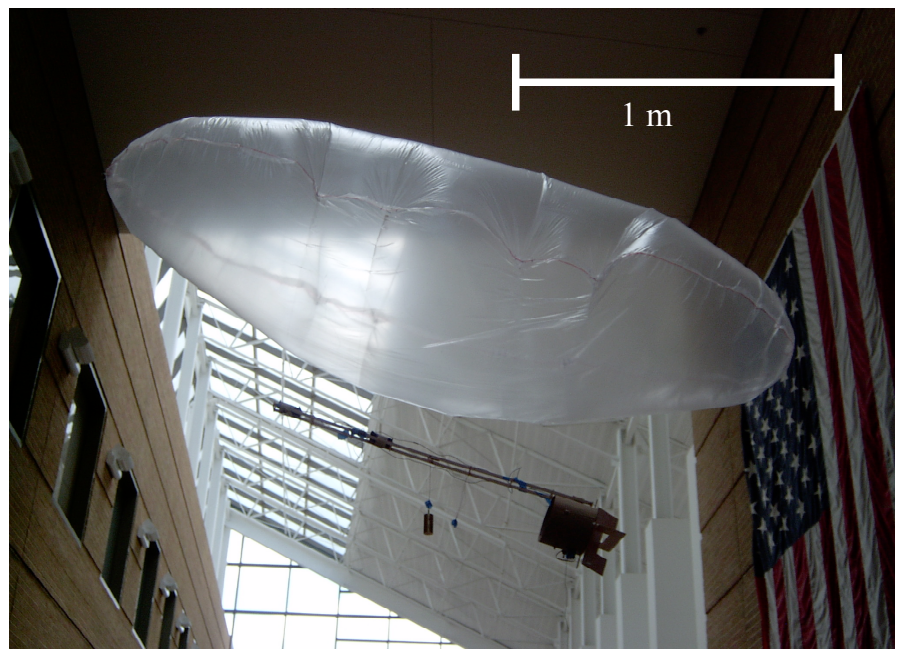

Figure 3. First Prototype Blimp: S1. A blimp with all of the components available to the students: a helium-filled envelope, payload, ducted fan propulsion system, radio-control system and rechargeable batteries. teaming experiences were composed of students selected randomly. Subsequent teams were selected by personality type ${ }^{6}$ and by the geographical location of their campus housing. The students were rearranged for each team assignment. This rearrangement may seem counterproductive, but it provided a mechanism to root out conflicts and to restart the teams with a relatively clean slate between each activity.

"Alien Autopsy": The first activity was the dissection of old analog radiosondes. These instruments were obtained as surplus equipment from the Department of Defense. The primary purpose of this task was to become familiar with real flight hardware, identify the components of the system, locate the center of mass and generate a detailed mass budget. The students were introduced to the entire flight system and its proper operation as part of Federal Aviation Regulations (e.g., FAR 101.1). Some of the components included batteries, sensors, transmitters, antennas, structural housing, and the main circuit board. The radiosonde lab provided hardware that allowed us to discuss an entire system and its various components and features. For example, the lengths of the antennas are tied to the frequencies of the transmitters. This lab also supplied raw material for subsequent labs: For example, the thermistor and bellows barometer were calibrated in later lab exercises. A schematic showing an aspect of this activity is shown in Figure 4.

Preliminary Teaming Exercise: The second activity was a teaming exercise to introduce notions of appropriate behavior, communication techniques, leadership, and personality types. The particular exercise involved solving a problem using only verbal communication. Each team member was given distinct and critical information, each needed to take an active role in the problem formulation and solution, and each needed to avoid certain behaviors like domination of the discussion or lack of participation that would hinder progress toward a solution. The exercise was followed by an extensive debriefing of helpful and unhelpful behaviors. 


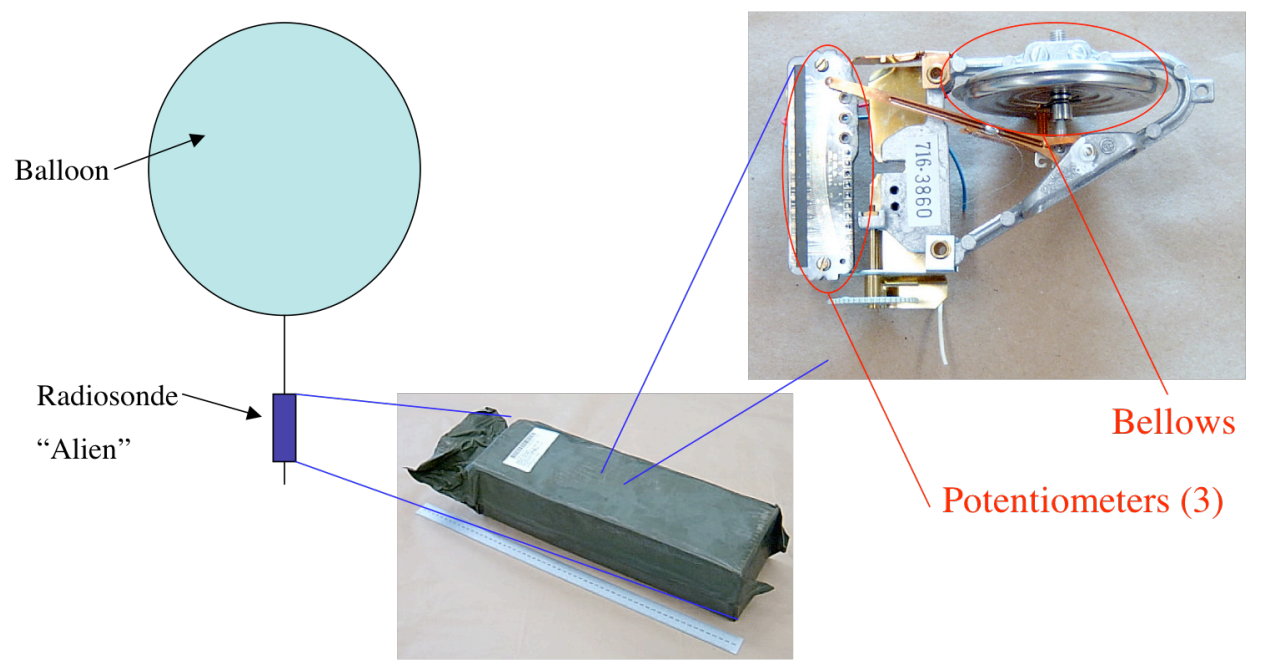

Figure 4. Radiosonde Autopsy. An analog radiosonde was studied and dissected to identify and characterize its components.

Balloon Project: The third activity involved a balloon competition where the teams designed, built and tested small balloons $(5 \mathrm{~g}$ dry mass limit) that they fabricated out of flat sheets of polyethylene; the competition was accompanied by oral presentations and written reports where each team described its design concept and rationale and the performance of its balloon. The competition was to raise a simple communication antenna (simulated by a $10 \mathrm{~m}$ length of fishing line) to a predetermined height in the shortest amount of time.

There were several purposes for this project. First, it prototyped all the major features of the final project in that the students had to designbuild-test a flight vehicle and present the results of their efforts in both an oral presentation and a written report. It gave them an opportunity to both succeed and fail on a small scale. Finally, it addressed the most troublesome technical aspect of the final project: the design, fabrication, and performance of the balloon envelope. One of the competition balloons is shown in Figure 5.

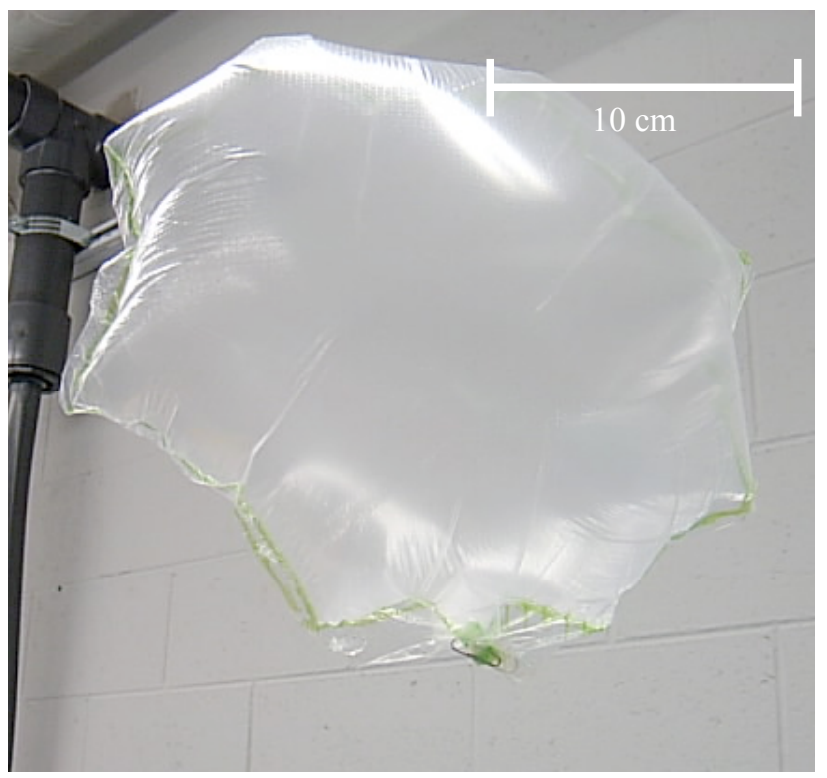

Figure 5. Example Balloon. A helium balloon fabricated from flat plastic stock, heat sealed around the periphery.

At first glance the balloon competition may seem too trivial technically, but it was not. The students learned how to estimate the lifting characteristics of flat sheets inflating into interesting shapes. There were students that painstakingly attempted elaborate mathematical models to predict aerodynamic shapes and volumes. Other students explored techniques for estimating volume. Still other students researched fabrication techniques to minimize seam sizes and shroud line attachment strategies that minimized mass and envelope deformation.

Blimp Project: The final project was for each team to design, build, test, and compete with a Helium-inflated blimp on an indoor course and to present and deliver oral presentations and written reports on the design, construction, and performance results of the team's blimp. The competition consisted of two parts: (1) a simple race along a straight $80 \mathrm{~m}$ course with a $180^{\circ}$ turn and (2) a reconnaissance task in minimum time using an on-board wireless video camera. The blimps were constrained to have a mass less than $1 \mathrm{~kg}$ and to use components provided 
by the instructors. These components included up to two motors (10 g mass and $10 \mathrm{~W}$ power), up to two NiMH battery packs (of either AAA or AA sizes), a 4-channel receiver, and any number and size of servos. The blimps were required to carry a $150 \mathrm{~g}$ payload. For the race this was a brass weight, and for the reconnaissance competition it was a camera system. In order to simulate 'deploying the blimp on Mars,' the entire system had to be storable within a $27 \mathrm{~cm} \mathrm{x} 55 \mathrm{~cm} \mathrm{x} 115 \mathrm{~cm}$ box, but the blimp could be manually assembled rather than automatically deployed. This storage constraint had the added practical benefit of making the projects more manageable in the lab, because it reduced the space needed to store the blimps during construction.

The purpose here was to make the project sufficiently complex both in terms of the design and the fabrication. Once an Earth-based model was identified, the students were required to scale their design for Martian operation. Fully assembled components were avoided wherever practical; raw stock material was preferred. For example, each team had to solder their own wiring harnesses.

The students were asked to use fabrication material provided in the lab, but they could propose their own materials and technologies - as long as they could be supplied to the entire class. For example, while most of the teams used balsa and bass wood construction, in the second offering of the course one of the teams also used structural elements fabricated out of small diameter model rocket tubes. The team performed a trade-off on a variety of paper and glass-epoxy reinforced tubes and found that under certain circumstances these thin-walled structures

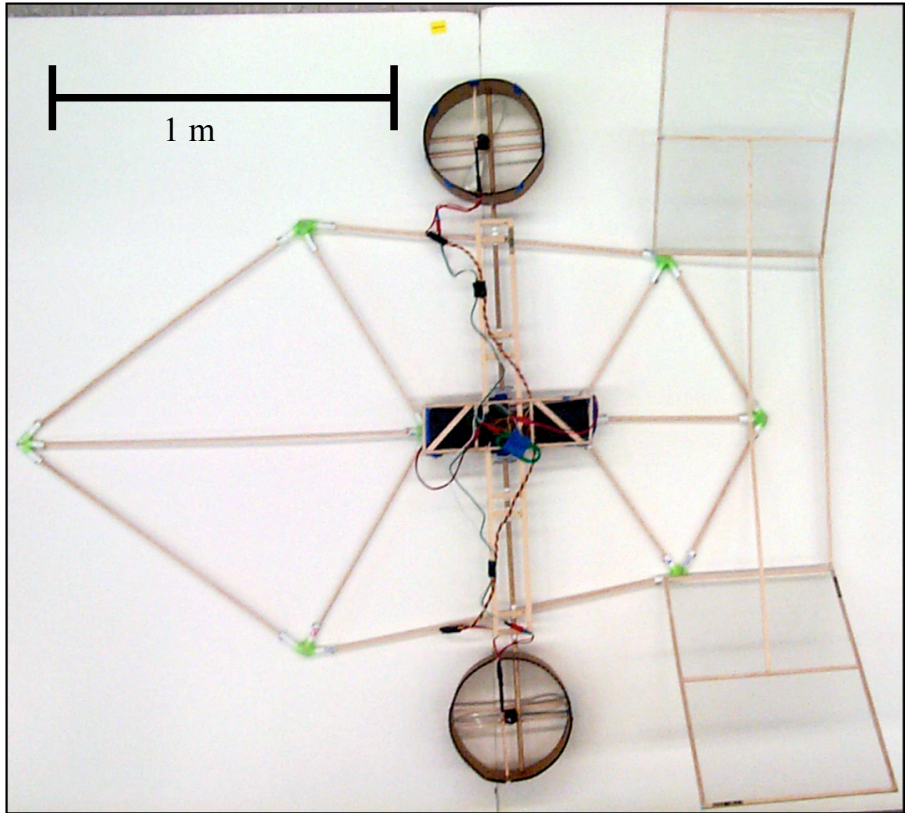

Figure 7. Example Student Gondola. A collapsible gondola structure, ducted motors, independent servos modified for $360^{\circ}$ rotation, battery packs and receiver. ${ }^{7}$ were superior to wood-trusses.

Innovations were encouraged. For example in Fall 2005 better servo performance was desired to improve the precision-pointing and control characteristics. The students adapted their lab experiences to solve their problem (several servos were sacrificed for the cause). The students ultimately modified the servos by removing the mechanical stops and either replacing the feed-back potentiometer with a multiple turn unit or mechanically decoupling it.

Another innovation has been to find means to effectively increase the number of control channels. Many teams have implemented various modes of blimp operation by mechanically coupling limit switches to a servo (to 're-wire' the blimp in flight), and a few teams have explored programming microcontrollers to decode and mix the pulsewidth-modulated signals coming from the receiver.

An example of a student project is shown in subsequent figures. Each individual student was required to independently present and report his or her own design. The team then 
performed a down-select of the technologies and ideas brought by each individual. A typical plan from a student team appears in Figure 6. The students then fabricated the most risky components (in this case the servos, the aerodynamic envelope shape and the poleattachment technique) and then completed fabricating the entire blimp system (the flight envelope and the gondola containing the propulsion, power, and control components). A photograph of the top-view of the gondola drawn in Figure 6 is shown in Figure 7, and a photograph of the completed blimp is shown in Figure 8.

\section{B. Supporting Lectures and Exercises}

The project team activities in Engineering 100-700 were supported by a series of regular lectures on technical and communications topics, individual labs and discussions, and other mostly individual activities. These later activities involved individual homework, written reports, and oral presentations. The technical topics were primarily taught by a technical faculty member, the communications topics mostly involved a technical communications instructor, and the labs were taught with student assistance.

The lectures consisted of three hours of contact time per week. They were offered in 1.5 hour periods on Tuesdays and Thursdays at $8 \mathrm{am}$. The Tuesday lectures covered mostly technical topics and were synchronized with the lab and discussion activities. Individual and team assignments were formally presented on Tuesdays; technical assignments were due a week later, and communication assignments were generally due in one week plus two or three days. The Tuesday technical lectures always involved debriefing the previous week's lab assignments and introducing the current week's lab, communication, and discussion activities. The Thursday communications lectures involved debriefing the previous week's communication assignment and providing details for the current week's communication assignment. A detailed script for the course is provided in Appendix A.

One of the interesting synergies that developed between the technical and technical communication instructors involved managing the student projects: it was very helpful to have two pairs of eyes reviewing the teams as they progressed in the lab and prepared each presentation or report. Because the technical and communication instructors were relatively knowledgeable about the other's content, they also developed interesting synergies in constructing and integrating assignments, in grading, and in developing efficiencies within the course.

\section{Technical Lectures}

The technical topics that were covered include an introduction to the standard atmosphere, Archimedes principle, the balance of vertical and transverse forces (e.g. lift vs. weight and thrust vs. drag), power systems, radio controlled devices and mechanisms. Dimensional analysis was introduced as a means to derive analytical relationships in the absence of physical conservation principles (introductory physics and calculus are not pre-requisites for this course). The role of the engineer with respect to the government was introduced by means of Federal

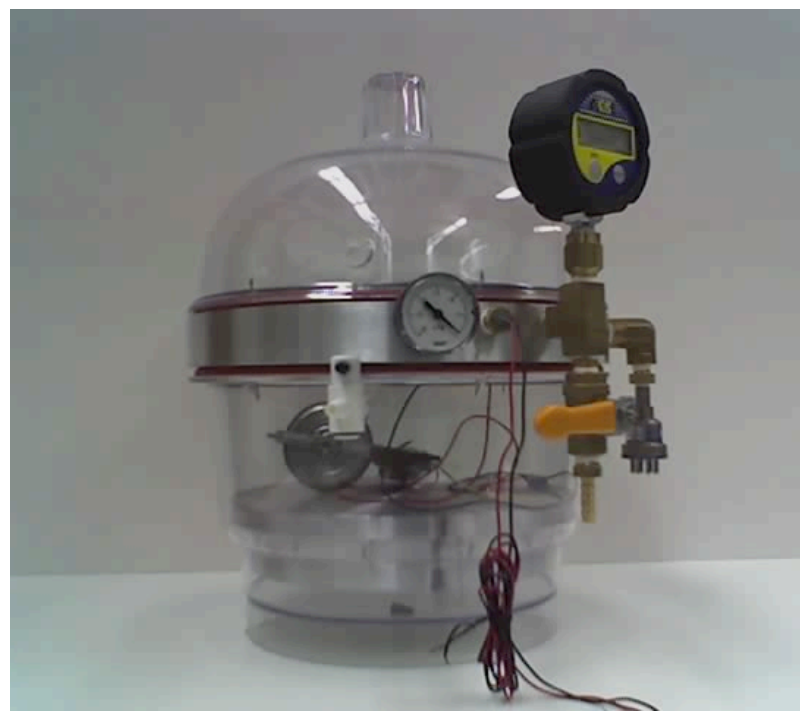

Figure 9. Small Vacuum Chamber. 9-inch diameter polycarbonate desiccators modified with an aluminum ring to allow electrical and pressure feed-through. The chamber contains a bellows barometer 
Aviation Regulations for radiosondes. Primary technical resources were course notes that were made available electronically as part of the laboratory writeups and reading in a textbook on blimps ${ }^{9}$ and introductory aerospace engineering ${ }^{10}$. Individual activities included pre- and post-lab homework exercises.

\section{Technical Communications}

This course is part of a required communications thread in the undergraduate curriculum. Consequently, communication instruction and exercises were provided in types and formats for written reports and oral presentations, audience needs, communication purpose, argumentation, readability and cohesion, visualization and visual aids, editing for emphasis and parallelism, and conversational style ${ }^{11}$. Report writing and oral presentation skills were exercised in a series of two memos, five technical reports and six oral presentations, covering material relevant to the FAA regulations for radiosondes, to each team's lab results, and to the design, construction, and performance of each team's balloon and blimp. Primary resources

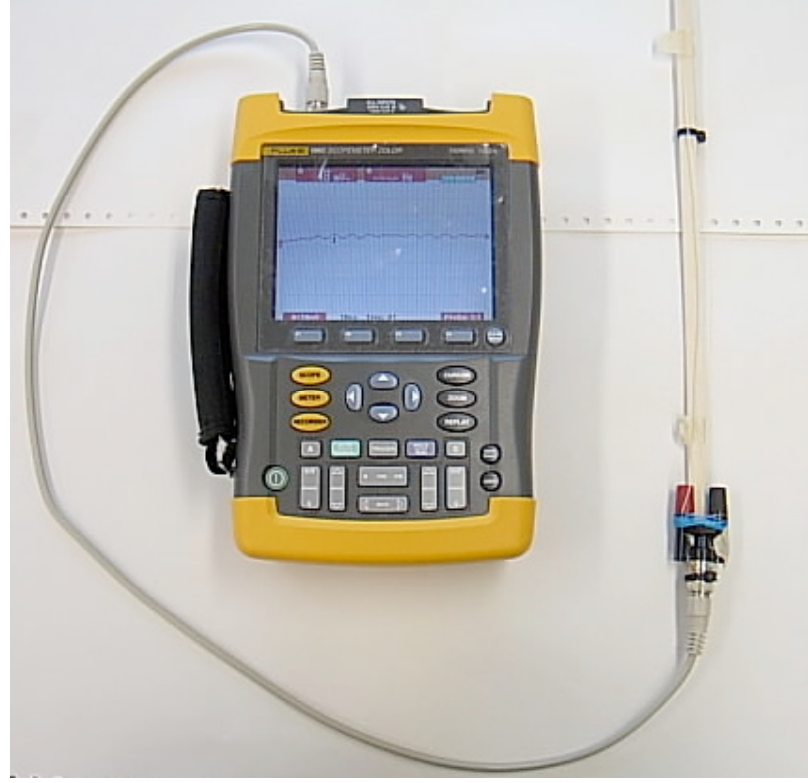

Figure 10. Oscilloscope and Spectrum Analyzer. Instrumentation and ground-plane antenna. were course notes provided in class and electronically from the course's technical communication text. ${ }^{11}$ Individual students and student teams did rewrites on communication assignments through the first two-thirds of the course.

\section{Laboratories/Discussion}

The laboratories were three hours long and involved the critical technologies that the students would need either to build their model blimp on Earth or to design their blimp for a Martian environment. These labs involved the

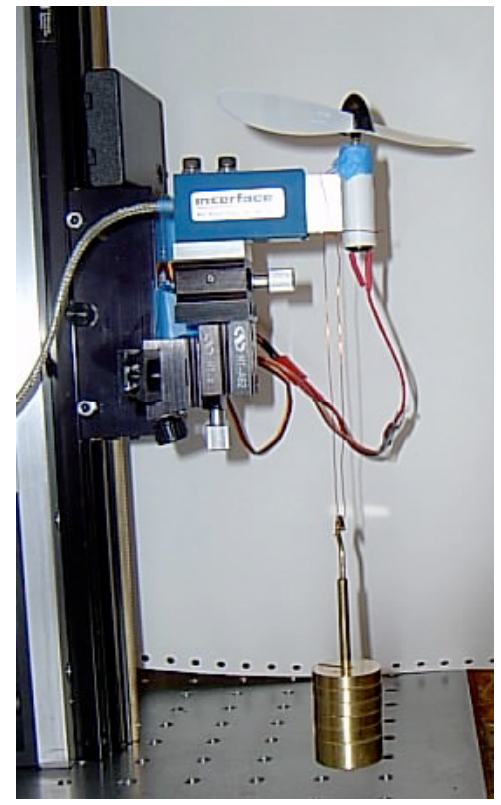

Figure 11. Thrust Stand. 25-lb load cell with motor and propeller assembly mounted. A brass calibration mass is suspended. following topics: (1) radiosonde dissection; (2) terrestrial and Martian atmospheres; (3) vertical equilibrium; (4) dimensional analysis; electrical power: solar cells and batteries; (6) radio control components: antennas, transmitters, receivers, and servos; (7) thrust vs drag: thrust stand testing of a motor and propeller; and (8) structures. In addition, the labs provided some time for the faculty to review with each team its progress in teamwork and communication projects, and some time for the students to fabricate and test their balloons and blimps, although the fabrication and testing process for the blimp, in particular, required significant additional time outside scheduled lab hours.

As a result of these labs, the individual students were introduced to a variety of instruments including power supplies, digital multi-meters, oscilloscopes, and spectrum analyzers. They examined the performance of thermistors, barometers, solar cells, transmitters and receivers. They used amplifiers, variable auto-transformers, translation stages, and rotation stages as well as basic instruments like calipers and micrometers. They were given introductory training in basic tools like a drill press, band saw, soldering iron, and small handheld plastic welder. Individually, they used these tools and instruments to perform their labs, and in teams they employed them to fabricate their flight vehicles.

Examples of some of the equipment used in the labs is discussed in the following. One lab exposed the sensors dissected from the radiosonde to a variety of simulated Martian conditions. This included immersing the thermistor in environments ranging from boiling water to solid $\mathrm{CO}_{2}$ to liquid $\mathrm{N}_{2}$ and then measuring its resistance. Interestingly, liquid $\mathrm{N}_{2}$ is sufficiently cold to exceed the resistance measurement range of our ohm-meter. This typically causes some consternation in that the 
thermistor appears to be broken as an open circuit, until it is removed from the bath and starts to warm up. The bellows barometer was calibrated in a modified vacuum chamber as shown Figure 9. As the chamber is pumped down, the bellows expand and the performance of the on-board potentiometer is measured.

Another lab examined the signals going in and out of the receiver. The primary instrument for this exercise is shown in Figure 10. The students used the oscilloscope and spectrum analysis functions to examine the signals between the receiver and the servos. Students also built their own antennas (e.g., simple di-poles and ground-plane) to characterize their performance as a function of distance and orientation.

One of the most useful labs involved characterizing the thrust performance of the motor and propeller as a function of supply voltage. The actual lab covered just the calibration of the loadcell and a single motor. Typically every team would assign one or more members to re-visit this experiment and explore the influence of varying the

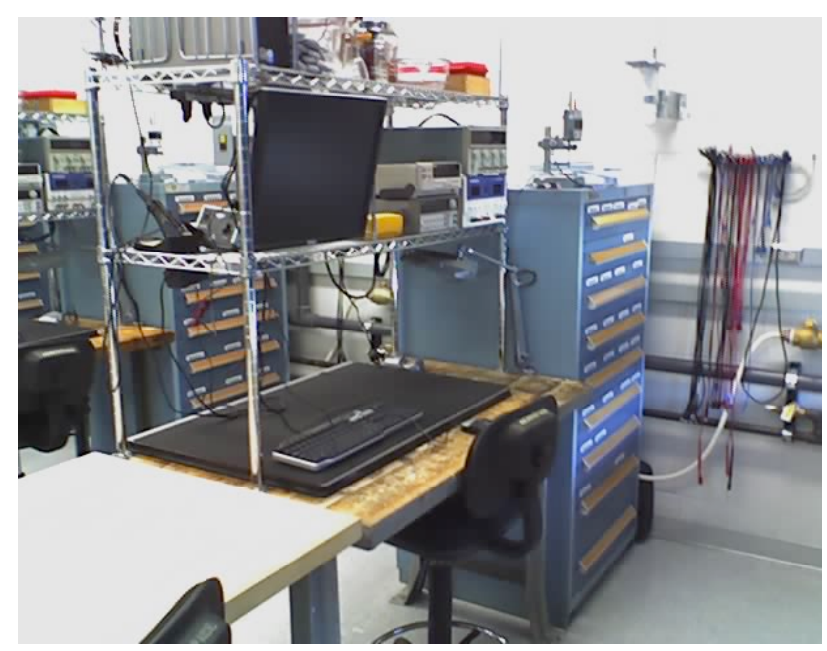

Figure 12. Typical Lab Station. A lab station for use by a pair of students. It consists of two table areas, instrumentation (e.g. power supply, oscilloscope), CAD workstation, secure storage area and building services (e.g. shop air, vacuum).

propeller diameter and adding a duct (students would investigate the influence of both diameter and length of the duct). Adding a duct involves its own design effort: Some teams have built multiple ducts while others have build a single one and cut down its length.

The lab facility itself was almost entirely self-contained and was housed in a $1000 \mathrm{sq} f \mathrm{ft}$ room that consisted of 5 lab stations (shown in Figure 12), two large $3 \mathrm{ft} \times 7 \mathrm{ft}$ work surfaces, and a $4 \mathrm{ft} \times 8 \mathrm{ft}$ optical table. The optical table was inherited from a research lab. It has a stainless steel surface with 1/4-20 NC threaded holes on a 1 inch square pattern. This optical table was an invaluable resource to layout envelope shapes (e.g. circles and ellipses). The large work surfaces were especially used during the fabrication of the blimp envelopes and the integration of the gondola with the envelope. The lab also housed the primary fabrication equipment, helium tanks as well as the portable carts to store the collapsed balloons and blimps. The facility allowed limited testing of the flight vehicle and was just down the hall from an $8 \mathrm{~m}$ wide by 50 meter long by 40 meter high atrium which functioned as the primary test range. The self-contained lab along with a co-located test facility allowed the students to efficiently progress through the design-build-test phases of their projects.

The lab accommodated 10 students in a section. Students primarily worked on their lab assignments in pairs and wrote-up their technical assignments individually. Teaming arrangements were made within the section to guarantee that there would be a time during the week (the common lab section) when the teams could meet. In the first two offerings, students from the Student Space Systems Fabrication Lab volunteered to assist and mentor in the labs. In the most recent offering, a Graduate Student Instructor (GSI) was employed. The labs were generally open Tuesday through Thursday and throughout the week before the competitions. The labs opened at $8 \mathrm{am}$ and closed at $10 \mathrm{pm}$.

\section{Results}

The course has now been offered three times, most recently in the Fall of 2006. The class was first prototyped at 30, then 40 students, and in the last offering at 50 students. For the earliest two offerings, some independent diagnostics in the form of course evaluations are available. In both cases, the results were spectacular in that the course was within a percent of achieving the highest marks possible. In addition all of the instructors achieved scores that were near the maximum possible. Perhaps the most interesting feature is that course was extremely intensive, yet it was tremendously popular. The students spent about $50 \%$ more time in the course as compared to a typical first-year Engineering 100 offering, yet they were able to master significantly more than $50 \%$ more content. Further, the course has led to some new positive behavior from its alumni. For example, some of the equipment used in the labs has been employed in subsequent student projects to perform more elaborate tests: the vacuum chamber, vacuum gages, and test procedure used in the atmospheric lab have since been employed by alumni student teams to calibrate their sensors in a high altitude rocket event in which they are participating. Students from 
this class that have subsequently become involved in zero gravity flights (NASA Space Grant C-9) have used the lab facilities, both during the term and in the summer, to prepare their payloads. This provides clear evidence that not only was the course a positive experience, but it has led to an increase in later capability of the students.

The blimp competitions have become events that have surpassed the instructor's original expectations. The competitions entail the students formally presenting their design and expected results (5-6 minutes per team). This is followed by the actual race and precision-pointing competitions. Parents, alumni of previous Eng 100-700 offerings, other faculty, and staff attend and bring their families (especially those with younger children), thereby providing a broad audience and somewhat festive atmosphere. Groups like the Solar Car team, Solar UAV, and the Student Space System Fabrication Lab attend the competition to recruit the first year students.

\section{Future Prospects and Challenges}

Even though there are some successful elements, there are still many challenges. Some of the challenges we have experienced on other team-based project courses. For example, it seems to be a persistent problem that there are some very capable students and students who do not participate fully - and it is sometimes difficult to fairly distinguish between the two sets in terms of grades. Perhaps the most pressing issues are how to further scale up the number of students and to take the course from an experimental footing and institutionalize it.

The current undergraduate Aerospace Engineering program at the University of Michigan graduates approximately 100 students annually. Approximately one half of the students in this course have expressed an interest in aerospace engineering, while the other half are interested in other areas of engineering. Students are formally surveyed upon entry to the college and express these interests. Alumni of the course have been tracked, and there have been only a few students who have been recruited into aerospace engineering as a result of this course. To make an impact on the aerospace program, we would at minimum have to double the course size and restrict the entry, or quadruple its size. Restricting entry to just students who have expressed an interest in aerospace engineering is not very attractive. This is because it would diminish the opportunity for students to explore a variety of technical areas, and we believe the course benefits from having students with diverse interests and capabilities. Options for increasing the enrollment include offering it every term and at least doubling the size of the labs.

Unfortunately, these options present some difficulties. To make this course successful, a very strict script needs to be followed. What this means is that there is very little room to cancel or reschedule a class period to adapt to unforeseen circumstances or to accommodate an instructor's schedule. This makes finding an instructor for the course even more challenging. Further, while the number of lab sections could be straightforwardly increased, there are currently certain choke points in the course. Some of these issues are straight forwardly mitigated, while some are more troublesome. Rather than having certain class-wide activities during the lecture period, these activities have been moved to the evening (e.g., the midterm exam). One of the more difficult problems is the week before the competitions -when everybody leaves the lectures and heads for the lab. What this means is that the lab space is bursting at the seams. A better strategy to more uniformly level the lab usage is needed. For instance, if the size of a class is doubled, we would likely offer two distinct $40-50$ person lecture sections to help mitigate these crowding events in the lab.

Finally the cost model for the course is not set-up for the long-term support of lab sections. Making this problem even worse are the 10-person labs. From one standpoint, these small sections are very desirable to give a smaller learning group, but it is expensive in terms of instructor time. Our experience with simply adding another student at each lab station (i.e., 3 people in front of the equipment rather than 2) is not desirable, because at least one person is frequently an observer rather than a participant in the exercise. We are currently exploring increasing the physical lab size and its infrastructure, staggering the lab assignments to reduce the need for additional infrastructure, and formalizing the role of the current volunteer/mentor/advisors.

\section{Acknowledgments}

A large number of alumni and industry representatives had a helpful hand in the development of this activity. The following is a partial list of individuals that either helped with the development or its themes. These include: P. Nuyen, J. McMasters and R. Bengilink, of Boeing; L. Nicolai, E. Boesinger, K. Albrecht and T. VanPelt of Lockheed Martin; R. Miller of Northrop-Grumman; E. Atkins and F. Severance of the University of Maryland and Western Michigan University, respectively. At the University of Michigan support and guidance was provided by T. Larrow, Instrument Maker; J. Szymusiak, J. Medlin, M. Long, undergraduates in Aerospace Engineering; F. Ford and S. Sandoval, undergraduate students in the Student Space Systems Fabrication Lab; and B. Gilchrist, A. Galimore, and T. Zurbuchen, of the faculty. Boeing Corporation in particular helped financially support the early development. 


\section{References}

${ }^{1}$ Thomas Liu, Christopher Deline, Rafael Ramos, Steven Sandoval, Ashley Smetana, Brian Gilchrist, Peter Washabaugh, Nilton Renno; “The Student Space Systems Fabrication Laboratory: An Approach To Space Systems Engineering Education” ASEE Annual Conference and Exposition, Chicago Il, 19-21 June 2006, Paper \#2006-1917

${ }^{2}$ E. M. Atkins, R.H. Miller, T. VanPelt, K.D. Shaw, W.B. Ribbens, D. S. Bernstein, and P. Washabaugh, 1998 "SOLUS: An Autonomous Aircraft for Flight Control and planning Research", The American Controls Conference Special Session on UAVs, Philadelphia PN, (ACC) vol. 2, pp. 689-693

${ }^{3}$ Hannah R. Goldberg, B.T. Cesul. Brian E. Gilchrist, 2002, "The Icarus Student Satellite - A Fully Autonomous Student Built Small Satellite for NASA", Proc. $16^{\text {th }}$ Annual, AIAA/Utah State University Conference on Small Satelites.

4 J. Smith, E. Valente, R. Eubank, and E. Atkins, "A Low-Cost Research Autopilot for System Identification," in Proc. AIAA Infotech@Aerospace Conference, Crystal City, VA, Sept. 2005, AIAA 2005-6963

${ }^{5}$ Newman, D. J., "Interactive Web-based and Hands-on Engineering Education: A Freshmen Aerospace and Design Course at MIT," International Conference on Engineering Education, Rio de Janeiro Brazil, August 17-20, 1998, Paper \# 448

6 "The Sixteen Types" Distributed by Prometheus Nemesis Book Company, Post Office Box 2748, Del Mar, CA 92014, C 1984, Gnosology Books Ltd.

7Aharon-Kuperman., "Farmers: Information Sharing" in The 1981 Annual Handbook for Group Facilitators, ed. John E. Jones, and J. William Pfeiffer, University Associates, Inc.

${ }^{8}$ D. Hawkins, R.P. Mioc, S. Ray, A. Richardson, S. Shah, "Team Shamu” December 3, 2005 Blimp Presentations.

${ }^{9}$ Airship Technology, Edited by Gabriel A. Khoury and J. David Gillet Cambridge University Press, 1999

${ }^{10}$ Introduction to Flight, J.D. Anderson, Jr. McGraw-Hill, New York, 1978

${ }^{11}$ Technical Writing and Professional Communications, $2^{\text {nd }}$ ed. L. Olsen and T. Huckin, McGraw-Hill, New York, 1991 


\section{Appendix A}

Detailed Course Description and Day-to-Day Activites

\begin{tabular}{|c|c|c|c|c|}
\hline $\begin{array}{l}\mathrm{W} \\
\#\end{array}$ & Date & Lecture. Labs and Discussion Activities & Loc. & Assignments \& Due Dates \\
\hline \multirow[t]{4}{*}{1} & \multirow[t]{3}{*}{$\begin{array}{c}\text { Sep } 5 \\
\text { Tue }\end{array}$} & $\begin{array}{l}\text { Lec: Course Intro and the "Mission to Mars"; } \\
\text { Diagnostic Introduction (FAR topic) } \\
\text { Read: Airship Technology: Ch. I } \\
\text { Review: Airship Technology: Ch. } 2 \text {; }\end{array}$ & $\begin{array}{l}1012 \\
\mathrm{FXB}\end{array}$ & $\begin{array}{l}\text { Assgn: Ind. Writing Diag. } \\
\text { Assgn: Lab } 1 \text { Ind. Tech. Q. } \\
\text { Assgn: Lab } 1 \text { Ind. Report }\end{array}$ \\
\hline & & $\begin{array}{l}\text { Lab 1: Alien Autopsy (Read: Handout) } \\
\text { Read: Airship Technology: } 216-217,235-238 \text {, } \\
\text { 242-245, } 285-288 \\
\text { Reference: Holman: Sect. } 6.6,8.5 \text { and } 9.8\end{array}$ & $\begin{array}{l}2251 \\
\text { FXB }\end{array}$ & \\
\hline & & $\begin{array}{l}\text { Dis 1: Aero Shop Training and Computer } \\
\text { Familiarization (Read: Handout) }\end{array}$ & $\begin{array}{l}2251 \\
\text { FXB }\end{array}$ & \\
\hline & $\begin{array}{c}7 \\
\text { Th }\end{array}$ & $\begin{array}{l}\text { Lec: Basic Communications: Reporting Types; } \\
\text { Technical Reports: Headings, Forewords, } \\
\text { Summaries; FAR exercise } \\
\text { Read: Olsen/Huckin, Ch. 12-13, 234-273 }\end{array}$ & $\begin{array}{l}1012 \\
\mathrm{FXB}\end{array}$ & $\begin{array}{l}\text { Due: Ind. Writing Diagnostic } \\
\text { Beginning of Class }\end{array}$ \\
\hline \multirow[t]{4}{*}{2} & \multirow[t]{3}{*}{$\begin{array}{l}12 \\
\text { Tue }\end{array}$} & $\begin{array}{l}\text { Lec: Introduction to Space Systems Engineering; } \\
\text { Summary for Report } 1 \text { (FAR Report) } \\
\text { Review: Airship Technology: Ch. } 18 \\
\text { Read: Airship Technology pg. } 211-216\end{array}$ & $\begin{array}{l}1012 \\
\mathrm{FXB}\end{array}$ & $\begin{array}{l}\text { Due: Lab } 1 \text { Ind. Tech. Q. } \\
\text { Assgn: Lab } 2 \text { Ind. Tech. Q. } \\
\text { Assgn: Lab } 2 \text { Ind. Report }\end{array}$ \\
\hline & & $\begin{array}{l}\text { Lab 2: Terrestrial and Martian Atmospheres; } \\
\text { Calibration Explanation and examples } \\
\text { (Read: CTools document) }\end{array}$ & $\begin{array}{l}2251 \\
\text { FXB }\end{array}$ & \\
\hline & & $\begin{array}{l}\text { Dis 2: Interactive Teaming and Communications } \\
\text { Exercise (Read: Handouts) }\end{array}$ & $\begin{array}{l}1044, \\
3072\end{array}$ & Assgn: Typing Survey \\
\hline & $\begin{array}{l}14 \\
\text { Th }\end{array}$ & $\begin{array}{l}\text { Lec: Introduction to Modern Computer Tools } \\
\text { Reference: "Engineering ... with Mathematica" } \\
\text { (Third Floor "Windows Training Rooms") }\end{array}$ & $\begin{array}{l}\text { Media } \\
\text { Union }\end{array}$ & Due: Lab 1 Ind. Report \\
\hline \multirow[t]{5}{*}{3} & \multirow[t]{3}{*}{$\begin{array}{l}19 \\
\text { Tue }\end{array}$} & $\begin{array}{l}\text { Lec: Balance of Vertical Forces and Fabrication; } \\
\text { Summary for Report } 2 \text { (Data Analysis) } \\
\text { Read: Airship Technology: pg. 216- } 223\end{array}$ & $\begin{array}{l}1012 \\
\mathrm{FXB}\end{array}$ & $\begin{array}{l}\text { Due: Lab } 2 \text { Ind. Tech Q. } \\
\text { Due: Typing Survey } \\
\text { Assgn: Lab } 3 \text { Ind Tech. Q. } \\
\text { Assgn: Team Balloon Comp. } \\
\text { Assgn: Proj Comm Assnmts }\end{array}$ \\
\hline & & $\begin{array}{l}\text { Lab 3: Lift vs Weight: The basic forces of } \\
\text { vertical motion (Read: CTools document) }\end{array}$ & $\begin{array}{l}2251 \\
\text { FXB }\end{array}$ & \\
\hline & & $\begin{array}{l}\text { Dis 3: Balloon Competition Teaming } \\
\text { (Read: Handout) } \\
\text { Foreword/Summary Workshop }\end{array}$ & Dis. & \\
\hline & $\begin{array}{l}21 \\
\text { Th }\end{array}$ & $\begin{array}{l}\text { Lec: Audience and Purpose; Oral Presentations; } \\
\text { Balloon Presentation Specifications } \\
\text { Read: Olsen/Huckin, Ch. 3,pp. } 56-70 ; C h .19 \text {, } \\
\text { pp. } 371-383\end{array}$ & $\begin{array}{l}1012 \\
\mathrm{FXB}\end{array}$ & Due: Lab 2 Ind. Report \\
\hline & $\begin{array}{l}22 \\
\text { Fri }\end{array}$ & $\begin{array}{l}\text { Optional/Open Lab: Balloon Fabrication and } \\
\text { Trials 10:00 am - 5:00pm }\end{array}$ & $\begin{array}{l}2251 \\
\text { FXB } \\
\text { Atrm. }\end{array}$ & \\
\hline
\end{tabular}




\begin{tabular}{|c|c|c|c|c|}
\hline \multirow[t]{11}{*}{4} & \multirow[t]{3}{*}{$\begin{array}{l}26 \\
\text { Tue }\end{array}$} & $\begin{array}{l}\text { Lec: Basic Modeling: Dimensional Analysis; } \\
\text { Presentation Review } \\
\text { Reference: "Similarity and Dim. Methods ..." }\end{array}$ & $\begin{array}{l}1012 \\
\mathrm{FXB}\end{array}$ & $\begin{array}{l}\text { Due: Lab } 3 \text { Ind. Tech. Q. } \\
\text { Assgn: Lab } 4 \text { Team Tech. Q. }\end{array}$ \\
\hline & & $\begin{array}{l}\text { Lab 4: Fabrication and Teaming Time } \\
\text { (Read: CTools Document) }\end{array}$ & $\begin{array}{l}2251 \\
\text { FXB } \\
\text { Atrm. }\end{array}$ & $\begin{array}{l}\text { Due: Lab } 4 \text { Team Tech. Q. } \\
\text { (Hand in before you leave) }\end{array}$ \\
\hline & & $\begin{array}{l}\text { Dis 4: Oral Presentation Conferences and } \\
\text { Balloon Teaming (Build and Test) }\end{array}$ & Dis. & \\
\hline & 27 & Optional/Open Lab: Balloon Fabrication and & 2251 & \\
\hline & Wed & Testing 10:00am - 5:00pm & $\begin{array}{l}\text { FXB } \\
\text { Atrm. }\end{array}$ & \\
\hline & 28 & Lec: Readability and Cohesion & 1012 & Assgn: Self and Peer \\
\hline & Th & $\begin{array}{l}\text { Read: Olsen/Huckin, Ch. 24-25, pp. } 440-468 \\
\text { Evening Oral Presentation Conferences (Appt.) }\end{array}$ & FXB & $\begin{array}{l}\text { Evaluations } \\
\text { Due: Oral Pres Rehearsal }\end{array}$ \\
\hline & 29 & Optional/Open Lab: Balloon Fabrication and & 2251 & \\
\hline & Fri & $\begin{array}{l}\text { Testing 10:00am-5:00pm } \\
\text { Evening Oral Presentation Conferences (Appt.) }\end{array}$ & FXB & \\
\hline & 30 & Balloon Competition (Handouts) & 1009 & Due: Team Oral Pres. \\
\hline & Sat & (Saturday 5:30 pm - 9:30pm) & $\begin{array}{l}\text { FXB } \\
\text { Atrm }\end{array}$ & Due: Team Balloon Comp. \\
\hline \multirow[t]{7}{*}{5} & \multirow{4}{*}{$\begin{array}{c}\text { Oct } 3 \\
\text { Tue }\end{array}$} & Lec: Modeling: Aerodynamic Forces: Drag & 1012 & Due: Self and Peer \\
\hline & & Review: Airship Technology: pg. $25-39$ & FXB & $\begin{array}{l}\text { Evaluations } \\
\text { Assgn: Lab } 5 \text { Ind. Tech. Q } \\
\text { Assgn: Lab } 5 \text { Ind. Report }\end{array}$ \\
\hline & & $\begin{array}{l}\text { Lab 5: Dimensional Similarity and the motion of } \\
\text { a Pendulum (Read CTools Document) }\end{array}$ & $\begin{array}{l}2251 \\
\mathrm{FXB}\end{array}$ & \\
\hline & & $\begin{array}{l}\text { Dis 5: Post Teaming Evaluation, Conversational } \\
\text { Style and Presentation Feedback (Handouts) }\end{array}$ & Dis. & \\
\hline & 5 & Lec: Visualization and Visual Aids & 1012 & \\
\hline & Th & Read: Olsen/Huckin, Ch 8-9, pp. 137-182 & FXB & \\
\hline & $\begin{array}{c}6 \\
\text { Fri }\end{array}$ & $\begin{array}{l}\text { E-mail to instructors; } \\
\text { Hard-copy to Professor Olsen ( } 305 \mathrm{EPB} \text { ) }\end{array}$ & & $\begin{array}{l}\text { Due: Team Final Balloon } \\
\text { Report (paper and electronic) }\end{array}$ \\
\hline \multirow[t]{8}{*}{6} & \multirow{2}{*}{$\begin{array}{c}10 \\
\text { Tue }\end{array}$} & Lec: Power and Propulsion; & 1012 & Due: Lab 5 Ind. Tech. Q. \\
\hline & & $\begin{array}{l}\text { Blimp Competition Introduction } \\
\text { Read: Airship Technology: pg. 107-112 } \\
\text { Review: Airship Technology: Ch } 16\end{array}$ & FXB & $\begin{array}{l}\text { Assgn: Lab } 6 \text { Ind. Tech Q. } \\
\text { Assgn: Team Blimp Comp. } \\
\text { Assgn: Team Oral Presns } \\
\text { Assgn: Reports }\end{array}$ \\
\hline & & Lab 6: Electrical Power: Batteries and Solar & 2251 & \\
\hline & & Cells (Read: CTools document) & FXB & \\
\hline & & Dis 6: Blimp Flying; Peer Evaluation Feedback; & FXB & \\
\hline & & Blimp Team Assignments & Atrm & \\
\hline & 12 & Lec: Exam Review; & 1012 & Due: Lab 5 Ind. Report \\
\hline & Th & Blimp Competition Detailed Specifications & FXB & \\
\hline
\end{tabular}




\begin{tabular}{|c|c|c|c|c|}
\hline \multirow[t]{6}{*}{7} & $\begin{array}{c}17 \\
\text { Tue }\end{array}$ & Fall Recess - NO CLASS & - & \\
\hline & & $\begin{array}{l}\text { Lab 7: Flow Visualization (CTools-Demo) } \\
\text { (Optional/Open Lab Sections) }\end{array}$ & $\begin{array}{l}2251 \\
\text { FXB }\end{array}$ & Assn: Lab 7 Ind. Tech. Q. \\
\hline & & $\begin{array}{l}\text { Dis 7: Blimp Competition Teaming } \\
\text { (Open Lab Sections) }\end{array}$ & $\begin{array}{l}2251 \\
\text { FXB }\end{array}$ & $\begin{array}{l}\text { Due: Lab } 7 \text { Ind. Tech. Q. } \\
\text { (Hand in before you leave) }\end{array}$ \\
\hline & $\begin{array}{l}19 \\
\text { Th }\end{array}$ & $\begin{array}{l}\text { Individual Presentation Expectations; } \\
\text { Example Problems }\end{array}$ & $\begin{array}{l}1012 \\
\text { FXB }\end{array}$ & \\
\hline & $6 \mathrm{pm}-$ & MIDTERM EXAM & 1109 & 1.5 Hour \\
\hline & $8 \mathrm{pm}$ & $\begin{array}{l}\text { Covering Lectures and Labs 1-5 (Technical and } \\
\text { Communication) and Balloon Competition }\end{array}$ & FXB & Open book and notes \\
\hline \multirow[t]{4}{*}{8} & $\begin{array}{l}24 \\
\text { Tue }\end{array}$ & $\begin{array}{l}\text { Lec: Flight Avionics Systems } \\
\text { Read: Airship Technology: Ch } 10\end{array}$ & $\begin{array}{l}1012 \\
\text { FXB }\end{array}$ & $\begin{array}{l}\text { Due: Lab } 6 \text { Ind. Tech Q. } \\
\text { Assgn: Lab } 8 \text { Ind. Tech Q. }\end{array}$ \\
\hline & & $\begin{array}{l}\text { Lab 8: Radio and Electrical Signals, Servos and } \\
\text { Controls (Read: CTools document) } \\
\text { Reference: }\end{array}$ & $\begin{array}{l}2251 \\
\mathrm{FXB}\end{array}$ & \\
\hline & & $\begin{array}{l}\text { Dis 8: Brief formal individual presentations to } \\
\text { exterior review team. }\end{array}$ & Dis. & $\begin{array}{l}\text { Due: Ind. Oral Presentation } \\
\text { on Preliminary Blimp Ideas }\end{array}$ \\
\hline & $\begin{array}{l}26 \\
\text { Th }\end{array}$ & $\begin{array}{l}\text { Lec: Editing Workshop: Parallelism } \\
\text { Read: Olsen/Huckin, Ch. 23, 428-439 }\end{array}$ & $\begin{array}{l}1012 \\
\text { FXB }\end{array}$ & \\
\hline \multirow[t]{5}{*}{9} & $\begin{array}{l}31 \\
\text { Tue }\end{array}$ & $\begin{array}{l}\text { Lec: Balance of Transverse Forces } \\
\text { Read: Airship Technology: pg. 25-39, 107-112 }\end{array}$ & $\begin{array}{l}1012 \\
\text { FXB }\end{array}$ & $\begin{array}{l}\text { Due: Lab } 8 \text { Ind. Tech Q. } \\
\text { Assgn: Lab } 9 \text { Ind. Tech Q. }\end{array}$ \\
\hline & & $\begin{array}{l}\text { Lab 9: Thrust vs. Drag: The basic forces of } \\
\text { transverse motion (Read: CTools document) }\end{array}$ & $\begin{array}{l}2251 \\
\text { FXB }\end{array}$ & \\
\hline & & Dis 9: Editing workshop (Handouts) & Dis. & \\
\hline & $\begin{array}{c}\text { Nov } 2 \\
\text { Th }\end{array}$ & $\begin{array}{l}\text { Lec: Editing for Emphasis } \\
\text { Read: Olsen/Huckin, Chs. 26-27,pp. 469-495 }\end{array}$ & $\begin{array}{l}1012 \\
\text { FXB }\end{array}$ & \\
\hline & $\begin{array}{c}3 \\
\mathrm{Fr}\end{array}$ & $\begin{array}{l}\text { E-mail to instructors and team-mates; } \\
\text { Hard-copy to Professor Olsen ( } 305 \mathrm{EPB})\end{array}$ & & $\begin{array}{l}\text { Due: Individual Blimp } \\
\text { Written Proposals }\end{array}$ \\
\hline \multirow[t]{4}{*}{10} & $\begin{array}{c}7 \\
\text { Tue }\end{array}$ & $\begin{array}{l}\text { Lec: Airship structures and materials } \\
\text { Review: Airship Technology: } \mathrm{Ch} 6 \text { and } 7\end{array}$ & $\begin{array}{l}1012 \\
\text { FXB }\end{array}$ & $\begin{array}{l}\text { Due: Lab } 9 \text { Ind. Tech Q. } \\
\text { Assgn: Lab } 10 \text { Ind. Tech Q. }\end{array}$ \\
\hline & & $\begin{array}{l}\text { Lab 10: Materials and structures (Read: CTools } \\
\text { document }\left({ }^{*}\right)\end{array}$ & $\begin{array}{l}2251 \\
\text { FXB }\end{array}$ & \\
\hline & & Dis 11: Brief team oral presentations & Dis. & $\begin{array}{l}\text { Due: Team Oral Pres. on } \\
\text { Primary Design }\end{array}$ \\
\hline & $\begin{array}{l}9 \\
\text { Th }\end{array}$ & $\begin{array}{l}\text { Lec: Argumentation } \\
\text { Read: Handouts; Olsen/Huckin, Ch. 4,pp. } 72-94\end{array}$ & $\begin{array}{l}1012 \\
\text { FXB }\end{array}$ & \\
\hline \multirow[t]{5}{*}{11} & $\begin{array}{c}14 \\
\text { Tue }\end{array}$ & $\begin{array}{l}\text { Lec: Balance of angular momentum. } \\
\text { Read: Airship Technology: pg. } 224-234\end{array}$ & $\begin{array}{l}1012 \\
\text { FXB }\end{array}$ & $\begin{array}{l}\text { Due: Lab } 10 \text { Ind. Tech Q. } \\
\text { Assgn: Lab } 11 \text { Team Tech Q. }\end{array}$ \\
\hline & & $\begin{array}{l}\text { Lab 11: Blimp Fabrication and Teaming Time } \\
\text { (Read: CTools document) }\end{array}$ & $\begin{array}{l}2251 \\
\text { FXB }\end{array}$ & $\begin{array}{l}\text { Due: Lab } 11 \text { Team Tech Q. } \\
\text { (Hand in before you leave) }\end{array}$ \\
\hline & & Dis 11: Blimp Competition Teaming & Dis. & 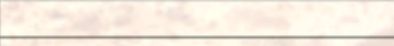 \\
\hline & $\begin{array}{l}16 \\
\text { Th }\end{array}$ & Lec: Argument and Oral Presentation Workshop & $\begin{array}{l}1012 \\
\text { FXB }\end{array}$ & 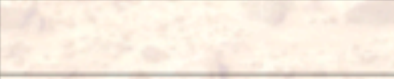 \\
\hline & $\begin{array}{l}17 \\
\text { Fri }\end{array}$ & $\begin{array}{l}\text { Optional/Open Lab: Blimp Fabrication and } \\
\text { Testing } \\
\text { 10:00 am - 5:00 pm }\end{array}$ & $\begin{array}{l}2251 \\
\text { FXB } \\
\text { Atrm }\end{array}$ & $\begin{array}{l}\text { Due: Team Blimp Written } \\
\text { Progress Report }\end{array}$ \\
\hline
\end{tabular}




\begin{tabular}{|c|c|c|c|c|}
\hline \multirow[t]{4}{*}{12} & $\begin{array}{l}21 \\
\text { Tue }\end{array}$ & $\begin{array}{l}\text { Lec: Class-wide Team Oral Presentation on } \\
\text { Blimp Progress } \\
\text { - CLASS STARTS AT } 8 \text { am SHARP! - }\end{array}$ & $\begin{array}{l}1012 \\
\mathrm{FXB}\end{array}$ & $\begin{array}{l}\text { Due: Blimp Team Oral } \\
\text { Presentation }\end{array}$ \\
\hline & & Lab 12: Optional/Open Blimp Teaming & $\begin{array}{l}2251 \\
\text { FXB }\end{array}$ & \\
\hline & & $\begin{array}{l}\text { Dis 12: Optional/Open Blimp Competition } \\
\text { Teaming }\end{array}$ & $\begin{array}{l}\text { FXB } \\
\text { Atrm }\end{array}$ & \\
\hline & $\begin{array}{l}23 \\
\text { Th }\end{array}$ & Thanksgiving Break - NO CLASS & - & \\
\hline \multirow[t]{6}{*}{13} & $\begin{array}{l}28 \\
\text { Tue }\end{array}$ & $\begin{array}{l}\text { Lec: Dynamical motion } \\
\text { Reference: Airship Technology: pg. } 39-54\end{array}$ & $\begin{array}{l}1012 \\
\text { FXB }\end{array}$ & \\
\hline & & Lab 13: Blimp Teaming & $\begin{array}{l}2251 \\
\text { FXB }\end{array}$ & \\
\hline & & Dis 13: Blimp Competition Teaming & Dis. & \\
\hline & $\begin{array}{l}30 \\
\text { Th }\end{array}$ & $\begin{array}{l}\text { Lec: Final Report Workshop } \\
\text { Evening Oral Presentation Conferences (Appt.) }\end{array}$ & $\begin{array}{l}1012 \\
\text { FXB }\end{array}$ & $\begin{array}{l}\text { Assgn: Self and Peer } \\
\text { Evaluations }\end{array}$ \\
\hline & $\begin{array}{l}\text { Dec } 1 \\
\text { Fri }\end{array}$ & $\begin{array}{l}\text { Optional/Open Lab: Blimp Fabrication and } \\
\text { Testing 10:00 am - 5:00 pm } \\
\text { Evening Oral Presentation Conferences (Appt.) }\end{array}$ & $\begin{array}{l}2251 \\
\text { FXB } \\
\text { Atrm }\end{array}$ & \\
\hline & $\begin{array}{c}2 \\
\text { Sat }\end{array}$ & $\begin{array}{l}\text { Blimp Competition } \\
\text { (Saturday } 9 \text { am - Noon) }\end{array}$ & $\begin{array}{l}\text { FXB } \\
\text { Atrm }\end{array}$ & $\begin{array}{l}\text { Due: Team Oral Presentation } \\
\text { (Advertisement) } \\
\text { Due: Team Blimp Comp. }\end{array}$ \\
\hline \multirow[t]{5}{*}{14} & $\begin{array}{c}5 \\
\text { Tue }\end{array}$ & $\begin{array}{l}\text { Lec: Final Report Issues; Cost, Risk Analysis, } \\
\text { and Case Studies } \\
\text { Review: Airship Technology: Ch } 17\end{array}$ & $\begin{array}{l}1012 \\
\mathrm{FXB}\end{array}$ & Assn: Lab 14 Ind. Tech. Q. \\
\hline & & $\begin{array}{l}\text { Lab 14: Post Competition Analysis } \\
\text { (Read: CTools Document) }\end{array}$ & $\begin{array}{l}2251 \\
\text { FXB }\end{array}$ & $\begin{array}{l}\text { Due: Lab } 14 \text { Ind. Tech. Q. } \\
\text { (Hand in before you leave) }\end{array}$ \\
\hline & & Dis 14: Blimp Competition Teaming Feedback & Dis. & $\begin{array}{l}\text { Due: Self and Peer } \\
\text { Evaluations }\end{array}$ \\
\hline & $\begin{array}{c}7 \\
\text { Th }\end{array}$ & Lec: Final Exam Review & $\begin{array}{l}1012 \\
\text { FXB }\end{array}$ & \\
\hline & $\begin{array}{l}8 \\
\text { Fri }\end{array}$ & $\begin{array}{l}\text { E-mail to instructors; } \\
\text { Hard-copy to Professor Olsen ( } 305 \text { EPB) }\end{array}$ & & $\begin{array}{l}\text { Due: Team Blimp Report } \\
\text { (paper and electronic) }\end{array}$ \\
\hline \multirow[t]{3}{*}{15} & $\begin{array}{c}12 \\
\text { Tue }\end{array}$ & $\begin{array}{l}\text { Class Summary and Lessons Learned } \\
\text { Future Directions and Course Survey }\end{array}$ & $\begin{array}{l}1012 \\
\text { FXB }\end{array}$ & \\
\hline & $\begin{array}{c}12 \\
\text { Tue }\end{array}$ & Lab Exam 10-4 (Sign up for a 1 hour time slot) & $\begin{array}{l}2251 \\
\text { FXB }\end{array}$ & $\begin{array}{l}1 \text { hour } \\
\text { Open Book, Notes \& Equip. }\end{array}$ \\
\hline & $\begin{array}{c}20 \\
\text { Wed }\end{array}$ & Final Exam 8:00 am (Sharp) - 10:00 am & $\begin{array}{l}\text { Likely } \\
1109 \\
\text { FXB }\end{array}$ & $\begin{array}{l}2 \text { Hour } \\
\text { Open book and notes }\end{array}$ \\
\hline
\end{tabular}

